\title{
Does international labour migration affect internal mobility in rural Norway?
}

\author{
Marie Holm Slettebak
}

\section{International and internal migration in the Norwegian countryside}

During the last two decades, Norway has evolved from a relatively homogenous country to a more multicultural one with international migrants in all parts of the country. According to register data from Statistics Norway, the proportion that are international migrants has increased from 5.3 per cent in 2000 to 14.4 per cent in 2019 (Statistics Norway n.d.). In addition to the arrival of refugees, it is particularly the enlargement of the European Union (EU) to the east, starting in 2004, that sparked an unprecedented increase in migration to Norway. These 'new' labour migrants, originating in eastern Europe, have, to a larger degree than other migrants, settled outside Norway's urban regions (Rye and Slettebak 2020). Therefore, many rural areas previously unfamiliar with international migration have experienced a large influx of labour migrants.

The large body of academic literature discussing the impact of international migration on native-born workers is mostly focused on wages, employment and other outcomes related to social mobility (See, e.g. Blau and Kahn 2012, Card 2009, Hoen, Markussen and Røed 2018). Less attention has been paid to the effect on geographic mobility. Particularly in Europe, this is an underresearched field. Further, the extant research has little focus on rural areas.

This chapter offers an examination of whether international labour migration to rural areas has had any effect on the internal mobility patterns of 'natives,' that is: people born in Norway (note that the term 'native,' which is commonly used in the literature to refer to someone that is born in a particular country, does not refer to ethnicity). Are international migrants only adding to the population, or are they replacing other in-migrants and pushing out similarly skilled workers, or creating new inflows of internal migrants? These questions are interesting and important for three reasons.

First, answering these questions provides important insight into the role of eastern European labour migrants in rural labour markets and their effect on Norwegian-born workers. Although there seems to be agreement in the public 
discourse that international labour migration has been positive for the Norwegian economy in general, worries regarding low-wage competition, displacement effects, and increasing social inequality have been voiced, researched, and debated (Friberg 2016). Second, the questions are demographically interesting particularly in rural areas. Many rural areas struggle with depopulation, and the literature abounds with research on how international migration can rescue rural regions that are struggling with diminishing and aging populations (see Aure, Førde and Magnussen 2018, Bayona-i-Carrasco and Gil-Alonso 2013). Hedberg and Haandrikman (2014) argue that international migrants are repopulating rural areas and can be seen as a rural 'demographic refill.' How international migration might also affect native-born inflows or outflows is an important part of this picture and of importance to rural communities' future demographic development. Third, these questions are methodologically interesting, as many studies use spatial variations in international migration to study the effects of migration on the labour market outcomes (wages, employment, etc.) of nativeborn workers. However, a potential weakness in previous studies is that labour markets are not closed, and people can selectively move in or out in response to the effects of migration from abroad. If so, the effects of international migration will be spread across the country and thus appear weaker (Borjas 2003). Although many researchers acknowledge this potential weakness, previous studies on the relationship between native-born internal mobility and international migration is limited. Most of the research has been conducted in the US, and only a few studies have focused on Europe.

The present analysis was conducted using Norwegian public register data from 2005 to 2015 at the municipality level. The Norwegian case is interesting due to the sudden increase in international labour migration. Further, the availability of high-quality register data at the municipality level provides an opportunity to examine the consequences of this increase in rural areas, which has been less explored, as international migration to western countries has, historically, been an urban phenomenon (see Rye and O’Reilly, Chapter 1).

\section{Connecting international and internal migration: theoretical perspectives}

According to King and Skeldon (2010), the field of migration studies has traditionally been split in two, as students of international and internal migration use different literatures, concepts, and methods. This chapter attempts to bridge this gap by discussing international and internal migration in interaction.

\section{The effect of international migration on native internal mobility}

According to Borjas (2003), the laws of supply and demand have clear implications for how international migration affects the labour market in the 
short run. The entry of international migrants into a certain area will create a supply shock that lowers the wages of competing workers, that is, workers who have the same types of skills. Workers with complementary skills, however, will experience increased wages as their skills become more valuable. Thus, according to classic economic theory, international migration should affect the wages and employment opportunities for native-born workers. However, a large number of studies have provided mixed and conflicting results (Blau and Kahn 2012, Card 2009, Borjas 2003). Many of these studies exploit the spatial variations in international migrants across the country to study the effect of international migration. The concern with this approach is that local labour markets are not closed - natives may respond to the impact of migration on the labour market by moving their labour or capital to another labour market, or they may avoid moving into a particular area. In this case, the effect of international migration is spread throughout the country, so that many towns and cities are affected - not just the places that received the international migrants (Borjas 2003). One of the most-cited examples in the literature is Card's (1990) analysis of the labour market in Miami, Florida, after the Mariel boatlift (the mass emigration of Cubans to the US in 1980), which increased Miami's labour force by seven per cent without affecting the wages or unemployment rates of native workers. Card suggests that one of the reasons for this wage stability was that the net migration of natives and earlier international migrants slowed considerably after the boatlift. This is considered a possible explanation for the mixed and conflicting results in the literature.

Despite the above, another possible explanation for the conflicting results is that the actual competition between labour migrants and natives is much more limited than classic economic theory would suggest. Within dual (or segmented) labour market theory, it is argued that the labour market has become increasingly divided into a primary and secondary sector (Doeringer and Piore 1971, Piore 1979). The jobs in the primary sector are secure and often high paying, and mainly reserved for natives. The jobs in the secondary sector are not secure, often low-paying and require few skills. Native workers are often unwilling to accept jobs in the secondary labour market, not just because of the low income they yield, as conventional economic theory would suggest, but because they signify or confer low status (Piore 1979). This might limit the competition between natives and labour migrants and explain why the effect on wages has been found to be small or non-existent in many studies.

Previous research on the connection between international migration and native-born internal mobility is limited, particularly in Europe. Much of the discussion also revolves around cities and metropolitan areas, while rural areas have not been in focus. In the US, where most of the empirical work on this topic is done, research has produced conflicting results. In 1996, demographer William Frey claimed that immigration was creating social and demographic divisions across the national landscape, which he labelled 
'demographic balkanization in America.' Part of the reason for this division, according to Frey, is that 'there is a unique, accentuated outmigration of lowincome, less-skilled domestic migrants from high immigration areas' (Frey 1996, 741). Wright, Ellis and Reibel (1997), however, argue that the cause of net migration's loss of natives in the large cities is more likely a result of industrial restructuring than of competition with international migrants. They found that the net migration of the native-born workers to metropolitan areas is either positively related or unrelated to international migration.

Labour economists have also presented contrasting results as they have entered the debate. Contrary to the demographic balkanisation hypothesis (that immigration leads to native out-migration), Card and DiNardo (2000) found that - if anything - increases of international migrants in specific skill groups lead to small increases in the population of native-born workers in the same skill group. Card (2001) found that intercity mobility rates of natives and earlier international migrants are insensitive to new inflows of international migrants. In other words, the effect of immigration was minimal, and, as a result, cities that received many international migrants expanded their labour markets. By contrast, Borjas, Freeman, and Katz (1997) found evidence that native migration flows respond to local influxes of international migrants. In a more recent study, Borjas (2006) found that international migration is associated with lower in-migration rates and higher out-migration rates of natives. At the metropolitan area level, he found that, for every 10 international migrants who choose to enter an area, between three and six natives will choose to not to live in that area.

In the few studies from Europe, the findings are less conflicting and suggest a clear connection between international migration and internal mobility. In the UK, Hatton and Tani (2005) finds consistently negative correlations between immigration to a region from abroad and in-migration from other regions. They conclude that these results suggest that internal migration is one of the mechanisms through which regional labour markets adjust to immigration shocks. In Italy, Brücker, Fachin, and Venturini (2011) have studied the effect of international migration on international mobility from poor to wealthy regions and found that the presence of international migrants significantly discourages internal mobility. Mocetti and Porello (2010) also investigated the relationship between native internal mobility and international migrants in Italy, but studied the differential impact by skill level. They found that international migration has a positive effect on inflows of highly educated natives, while displacing low-educated natives.

Summing up, though previous research is limited, the majority has found a connection between international migration and native-born workers' internal mobility. Although a few US studies find that immigration leads to increases in the native population, most of the studies find that higher rates of immigration are followed by fewer natives choosing to live in a particular area, either by moving out or avoiding moving in. 


\section{Relevant factors beyond the labour market}

While this study's main argument is that the possible connection between international labour migration and native-born internal mobility is due to mechanisms in the labour market, there are also other factors beyond the labour market that are relevant to consider. First, the housing market can influence decisions about moving. An increasing number of labour migrants in a municipality often puts pressure on the housing market, leading to higher prices (Gonzalez and Ortega 2013, Saiz 2007). This might also affect nativeborn migration. Mocetti and Porello (2010) found a significant negative effect of higher housing prices on native net migration, which suggests that higher housing costs reduce labour mobility and deflate income prospects in a region.

Second, a large and diverse body of literature exists on the issue of residential segregation and international migrants' concentration in urban neighbourhoods. Several studies have found that the native-born population increasingly flees or/and avoids neighbourhoods with high proportions of international migrants (Brama 2006, Crowder, Hall, and Tolnay 2011, Wessel and Nordvik 2019). Although this strand of the literature cannot be ruled irrelevant for this study, it can be argued that the processes at the neighbourhood level in the cities are distinct from migration at the municipality level in rural areas, the topic with which this study is concerned. While attitudes toward international migrants or high-immigration areas might affect neighbourhood choices within cities, these are less likely to lead to migration patterns across greater distances.

\section{The Norwegian case}

While previous research has treated international migrants as one group, the focus in this chapter is on a specific group of international migrants, namely labour migrants from the newest EU countries. In 2005, approximately 2,600 labour migrants from post-communist EU countries (in this chapter referred to as 'EU11 labour migrants') were residing in Norway, compared with more than 115,000 in 2015. While previous labour migrants and refugees often settled in urban areas, the labour migrants from EU11 displayed a settlement pattern more representative of the general population. In 2015, 2.24 per cent of the population in the average rural municipality were EU11 labour migrants, compared with 2.10 per cent in urban municipalities. These people were, however, very unevenly distributed across rural Norway - some municipalities have received many, while others have received very few (Rye and Slettebak 2020).

The majority - more than 75 per cent - of EU11 labour migrants in Norway are registered as being employed in manual and low-skilled work. They are overrepresented in agriculture, fish processing, the shipyard industry, hotels, cleaning, construction work, and transportation. Only six per cent work in 
technical, administrative, or academic occupations, compared with 50 per cent of Norwegian-born workers (Friberg 2016). This means that Norwegianborn workers with higher levels of education face little competition from this group of migrants, while the low-skilled potentially do.

To this author's knowledge, no previous research has been conducted in Norway to study the connection between international migrants and Norwegian-born workers' internal mobility. However, some studies exist on the effects of international migration on native workers' wages and employment. Bratsberg and Raaum (2012) studied the construction industry and found that professions with high international labour migration experience significantly lower growth in wages. They also found that international labour migration increases the probability of low-skilled natives leaving the workforce. Bratsberg et al. (2014), looking at the entire Norwegian labour market, found that migration from low-income countries affects the income and employment of international migrants already in Norway, but has less of an effect on Norwegian-born workers. More recently, Hoen, Markussen and Røed (2018) found that migration from low-income countries has steepened the social gradient in natives' labour market outcomes. While exposure to migrants from low-income countries lowers wages and employment for lower-class natives, it affects natives in the higher classes by raising their expected earnings. Similarly, Slettebak (in-press) found that labour migration increases income inequality within the native population in rural areas.

Although the findings are somewhat mixed, previous research suggests that international labour migration has affected the wages and employment of Norwegian-born workers. The question to be answered in this chapter is whether these effects affect settlement decisions. An important question in this regard is whether employment/job opportunities are important factors for explaining out- and in-migration in rural Norway. Sørlie (2009) argues that employment is actually a more important motivation for moving into or staying in the peripheral regions of Norway than in the country in general. Part of the reason for this phenomenon is that there are fewer available jobs in the periphery, which puts more focus on the necessity of employment. Similarly, Grimsrud (2011) found that work and family are the most important reasons for in-migration to rural areas, and that the "counterurbanisation story'- depicting urban to rural migration as motivated by antiurban preferences - is not a good fit for rural Norway.

Assuming that low-skilled labour migrants have a negative effect on the employment and wages of less-ducated workers and a positive effect on the employment of highly educated ones, and assuming that this is relevant for their settlement decisions, the following hypotheses can be tested:

H1: Increasing international labour migration is followed by higher outmigration of less-educated Norwegian-born people. 
$\mathrm{H} 2$ : Increasing international labour migration is followed by lower inmigration of less-educated Norwegian-born people.

H3: Increasing international labour migration is followed by higher inmigration of highly educated Norwegian-born people.

H4: Increasing international labour migration is followed by lower outmigration of highly educated Norwegian-born people.

It is important to note that there is an essential difference among the hypotheses concerning out- and in-migration. For instance, H1 assumes that the weakened position of lower educated people in the labour market will increase their chance of leaving the particular municipality. H2, however, simply assumes that lower educated people, to a larger degree, will avoid the particular municipality. It is possible to argue that leaving a place is a much stronger statement than avoiding one place in favour of another.

Another relevant point in this regard is that Norway and the other Nordic countries are characterised by a large welfare state with universal benefits, including free education and health care. Being a part of what Esping-Andersen (1990) calls the 'social democratic welfare states regimes,' the dependence on the market is weaker in Norway than in other less decommodifying welfare states, such as in the US, UK, or southern Europe. Such features of the Norwegian case could imply weaker incentives to relocate for economic reasons.

Lastly, Norway's geographic and demographic features have implications for the frequency of migration. In many western European countries, people move frequently and in all directions among populous regions with short distances between them. Large distances and relatively small populations, however, characterise the Nordic countries. This has implications for mobility patterns. In Norway, relocation often implies moving to another part of the country and across a great distance. Therefore, it is natural, according to Sørlie (2010), that, compared with the populations of many other western European countries, Norwegians move less often.

\section{Researching movements in rural municipalities}

The analysis is based on municipal level register data from 2005 to 2015. All data were obtained or ordered from Statistics Norway or Microdata.no, a service that gives researchers access to microdata from Statistics Norway.

\section{Defining the 'rural'}

This analysis focuses on rural municipalities. When defining what constitutes a rural or urban municipality, a conventional approach, building on Almås and Elden (1997) and Farstad, Rye, and Almås (2009), has been applied to define rural municipalities according to three criteria: 
1) Centrality: this refers to the number of jobs and service functions that can be reached by car in 90 minutes for the average inhabitant in the municipality. A scale from one to six is constructed, where 'six' is the least central (Statistics Norway's centrality scale, see Høydahl 2017). Municipalities at levels five and six (238 municipalities) are defined as 'rural.' These are the municipalities described as least and second-least central by Statistics Norway.

2) Settlement density: this refers to the percentage of the population residing in 'sparsely populated areas' (settlements with more than 200 people in houses less than 50 meters apart are not sparsely populated). Municipalities are defined as 'rural' according to this criterion if more than 50 per cent of the population resided in a sparsely populated area in 2016.

3) Labour markets: this is the percentage of the working population employed in the primary sector (agriculture, fisheries, forestry). Municipalities are defined as 'rural' according to this criterion if more than seven per cent of the working population was employed in the primary sector in 2016.

A municipality is categorised as rural if at least one of these criteria are met; this yielded 271 'rural' municipalities in Norway, out of 426. Roughly 18 per cent of the Norwegian population resides in a rural municipality. The other remaining municipalities are neither peripheral nor characterised by a dispersed settlement structure or strong primary industries; they are defined as 'urban.'

\section{Measuring internal mobility among Norwegian-born people}

The dependent variables measure the municipal out- and in-migration of high and low educated Norwegian-born people. The dependent variables were constructed using Microdata.no. Due to confidentiality concerns, the output from this platform is noise inflicted. However, no counts (numbers) are noise inflicted by more than $+/-5$ and the noise is random and should not affect the conclusion of this analysis.

Out-migration is defined as being registered as settled in the municipality in year $t$, but registered in a different municipality in year $\mathrm{t}+1$ (1 January). Inmigration is defined as being registered as settled in the municipality in year $t$, but registered in a different municipality in year $\mathrm{t}-1$. Only internal mobility is included. Compared with internal mobility, the frequency of international in- and out-migration is very low among Norwegians, thus the exclusion of this type of mobility is not expected to affect the results.

A distinction is made between less and highly educated people to look for patterns in mobility based on educational level. In- and out-migrants over the age of 25 are categorised as 'highly educated' if they have education to the 
college or university level, and as 'less educated' if they do not have such an education. The age limit of 25 was set to avoid including too many children and young adults who have not yet finished their education.

This resulted in six dependent variables: out-migration (all), out-migration of the highly educated, out-migration of the less educated, in-migration (all), in-migration of the highly educated and in-migration of the less educated. The variables are measured as proportions, that is, what per cent moved out or in during a specific year (number/total number in group*100).

\section{Independent variables}

In this chapter, 'international migrants' are defined as people born in a foreign country with two foreign-born parents. International migrants are only registered as settled in a municipality if they have lived in Norway for at least six months. This means that migrants on shorter stays, for example seasonal workers staying only for the summer, are not included in the data. This is due to theoretical considerations and lack of data for this group over time.

The main independent variable measures the proportion of EU11 labour migrants in a municipality each year. EU11 refers to migrants from the (post-communist) countries that joined the EU after 2004. This includes migrants from Poland, Lithuania, Latvia, Estonia, Czech Republic, Slovakia, Hungary, Slovenia, Romania, Croatia, and Bulgaria. The term 'labour migrant' refers to their main reason for migration and has been used in Norwegian registries since 1989. This includes those who have been granted a work permit or, in the case of EU/EEA (European Economic Area) citizens, who are registered via the EEA registration (Dzamarija 2013). All EU/EEA citizens who intend to stay in Norway for more than three months need to register.

In addition, the study controls for refugees, a term that includes all migrants who have a residence permit in Norway and where refugee status has been given as the reason for their residence application. This includes asylum seekers who have been granted residence, those who have been granted residence on humanitarian grounds and quota refugees (UN refugees) (Dzamarija 2013).

Unemployment measures the proportion of the labour force (workers 1574 years) who are registered as unemployed. Monthly data were obtained from Statistics Norway for 2005 through 2014. The variable was constructed by calculating the average for each year.

Median income measures the median income for households after tax each year. The numbers have been adjusted for inflation using 2015 as the base. The numbers are divided by 100,000 to obtain larger units. Descriptive statistics for all variables are presented in Table 11.1. 


\section{Testing the connection between international labour migration and natives' internal mobility patterns}

The analysis uses fixed effects linear regression models, which explore the relationship between the independent and dependent variables within a given entity, municipalities in this case. Fixed effects models remove the effect of all time-invariant variables, which means that only variables that have changed between 2005 and 2015 can affect the results. All models are also controlled for year, making them time and entity fixed effects regression models.

Table 11.1 displays the results of a fixed effects linear regression with two dependent variables, the out- and in-migration of Norwegian-born people in rural municipalities. Starting with out-migration, we see that the effect is close to zero and not statistically significant. Controlling for changes in the proportion of refugees, unemployment, and median income (adjusted for inflation) does not alter this result, but clearly shows that increasing unemployment and median income are followed by higher levels of out-migration. Moving on to the in-migration models, we see that, when the proportion of EU11 labour migrants increases, the in-migration rate increases, but again the results are not significant.

Overall, Table 11.2 depicts a very weak and insignificant relationship between the arrival of EU11 labour migrants and the general moving patterns of Norwegian-born people in rural regions.

In Table 11.3, however, the dependent variables distinguish between the outand in-migration of people with lower and higher education, and a pattern emerges between EU11 labour migrants and the moving patterns of higher educated Norwegian-born people. When the proportion of EU11 labour migrants increases with one per cent, the out-migration of higher educated people decreases, and the rate of in-migration increases. The effect on the less educated is close to zero and not significant.

Table I I.I Descriptive statistics (variables used in Tables II.2 and II.3)

\begin{tabular}{llccl}
\hline & Min & Max & Mean & SD \\
\hline Out-migration & 1.10 & 9.20 & 3.39 & 1.01 \\
In-migration & 0 & 9.2 & 2.90 & 1.02 \\
Out-migration, low educated & 0 & 8.79 & 2.04 & 0.83 \\
Out-migration, high educated & 0 & 26.67 & 5.40 & 3.01 \\
In-migration, low educated & 0 & 8.15 & 2.08 & 0.89 \\
In-migration, high educated & 0 & 69.51 & 4.26 & 3.15 \\
EUII labour migrants & 0 & 14.52 & 1.01 & 1.55 \\
Refugees & 0 & 9.60 & 0.88 & 1.01 \\
Unemployment & 0.27 & 10.31 & 2.43 & 1.30 \\
Median income (I00,000 & 3.03 & 6.57 & 4.39 & 0.55 \\
$\quad$ NOK) - adjusted & & & & \\
\hline
\end{tabular}

Source: Statistics Norway and Microdata.no 
Table II.2 Fixed effects linear regression, out-migration and in-migration of Norwegian-born

\begin{tabular}{lllll}
\hline & Out-migration & \multicolumn{2}{l}{ In-migration } \\
\hline EUII labour migrants, t-I & -0.009 & -0.008 & 0.012 & 0.005 \\
& $(0.016)$ & $(0.017)$ & $(0.017)$ & $(0.017)$ \\
Refugees t-I & & -0.028 & & -0.043 \\
& & $(0.033)$ & & $(0.033)$ \\
Unemployment t-I & & $\mathbf{0 . 0 8 7 * * *}$ & & -0.022 \\
& & $(0.023)$ & & $(0.024)$ \\
Median income t-I & & $0.350^{* *}$ & & -0.220 \\
(adjusted) & & $(0.119)$ & & $(0.121)$ \\
Constant & $3.524^{* * *}$ & $1.902^{* * *}$ & $2.776^{* * * *}$ & $3.726^{* * *}$ \\
& $(0.041)$ & $(0.477)$ & $(0.04 I)$ & $(0.486)$ \\
R2within & 0.025 & 0.034 & 0.023 & 0.025 \\
$N$ & 2,710 & 2,710 & 2,710 & 2,710 \\
Year control & Yes & Yes & Yes & Yes \\
\hline
\end{tabular}

Standard errors in parenthesis

*** Sig<=0.001, **Sig<=0.01, *Sig<=0.05

Source: Statistics Norway and Microdata.no

Two issues can be raised concerning these models. First, changes in the proportion of labour migrants can be affected - particularly in smaller municipalities - by the dependent variables. For instance, the number of labour migrants may remain unchanged, but the proportion may increase due to the out-migration of Norwegian-born people. Second, it could be problematic to study proportions in the smallest municipalities, as they have only a few hundred inhabitants. In the descriptive statistics in Table 11.1, it is clear that relative measures, particularly of the in- and out-migration of highly educated people, are problematic when the original numbers are too small.

Neither of these weaknesses is present in models with frequencies instead of proportions. Further, both weaknesses are mainly related to the smallest municipalities. Additional analyses have been conducted to test the robustness of the models presented; first by running the analysis from Table 11.3, but without the smallest municipalities included, and, second, by running the analyses using frequencies instead of proportions.

Only the coefficient for EU11 migrants is presented in Table 11.4, but all control variables used in Table 11.3 were also used in these analyses. The first row shows the results from the models, which are identical to the models in Table 11.3, though the smallest municipalities (those with fewer than 900 inhabitants) are excluded. The effect of EU11 labour migration on out- and in-migration of Norwegian-born people is strongly reduced and no longer significant, which suggests that a few very small municipalities affected the regression and might have overestimated the effect. 
Table II.3 Fixed effects linear regression, out- and in-migration of low- and high-educated Norwegian-born

\begin{tabular}{|c|c|c|c|c|c|c|c|c|}
\hline \multirow[b]{2}{*}{ EUII labour migrants, t-I } & \multicolumn{2}{|c|}{ Out-migration, low educated } & \multicolumn{2}{|c|}{$\begin{array}{l}\text { Out-migration, } \\
\text { high educated }\end{array}$} & \multicolumn{2}{|c|}{$\begin{array}{l}\text { In-migration, } \\
\text { low educated }\end{array}$} & \multicolumn{2}{|c|}{$\begin{array}{l}\text { In-migration, } \\
\text { high educated }\end{array}$} \\
\hline & $\begin{array}{l}-0.020 \\
(0.016)\end{array}$ & $\begin{array}{l}-0.018 \\
(0.017)\end{array}$ & $\begin{array}{l}-0.148 * \\
(0.062)\end{array}$ & $\begin{array}{l}-0.159 * \\
(0.065)\end{array}$ & $\begin{array}{l}0.013 \\
(0.016)\end{array}$ & $\begin{array}{c}0.015 \\
(0.017)\end{array}$ & $\begin{array}{l}\mathbf{0 . 1 5 5 *} \\
(0.072)\end{array}$ & $\begin{array}{l}\mathbf{0 . 1 5 4} * \\
(0.075)\end{array}$ \\
\hline Refugees t-I & & $\begin{array}{l}-0.021 \\
(0.033)\end{array}$ & & $\begin{array}{l}-0.117 \\
(0.124)\end{array}$ & & $\begin{array}{l}-0.030 \\
(0.032)\end{array}$ & & $\begin{array}{l}-0.062 \\
(0.143)\end{array}$ \\
\hline Unemployment t-I & & $\begin{array}{l}\mathbf{0 . 0 6 3} * * \\
(0.023)\end{array}$ & & $\begin{array}{c}0.142 \\
(0.088)\end{array}$ & & $\begin{array}{l}0.021 \\
(0.023)\end{array}$ & & $\begin{array}{l}-0.323 * * \\
(0.101)\end{array}$ \\
\hline Median income t-I & & $\begin{array}{l}0.306 * \\
(0.119)\end{array}$ & & $\begin{array}{c}0.285 \\
(0.454)\end{array}$ & & $\begin{array}{l}0.191 \\
(0.118)\end{array}$ & & $\begin{array}{l}-0.997 \\
(0.523)\end{array}$ \\
\hline Constant & $\begin{array}{l}2.109 * * * * \\
(0.041)\end{array}$ & $\begin{array}{c}0.736 \\
(0.478)\end{array}$ & $\begin{array}{l}6.808 \text { ***** } \\
(0.154)\end{array}$ & $\begin{array}{l}5.309 * * \\
(1.818)\end{array}$ & $\begin{array}{l}2.021^{* * * *} \\
(0.040)\end{array}$ & $\begin{array}{l}\text { I.237** } \\
(0.472)\end{array}$ & $\begin{array}{l}4.291^{* * * *} \\
(0.178)\end{array}$ & $\begin{array}{l}9.269 * * * \\
(2.091)\end{array}$ \\
\hline R2within & 0.015 & 0.021 & 0.068 & 0.070 & 0.017 & 0.019 & 0.007 & 0.012 \\
\hline $\mathrm{N}$ & 2,710 & 2,710 & 2,710 & 2,710 & 2,710 & 2,710 & 2,710 & 2,710 \\
\hline Year control & Yes & Yes & Yes & Yes & Yes & Yes & Yes & Yes \\
\hline
\end{tabular}

Standard errors in parenthesis

$* * *$ Sig $<=0.00 \mathrm{I}, * *$ Sig $<=0.01$, *Sig $<=0.05$

Source: Statistics Norway and Microdata.no 
Table II.4 Sensitivity analysis. Fixed effects linear regression with different model specifications

\begin{tabular}{|c|c|c|c|c|}
\hline & $\begin{array}{l}\text { Out-migration, } \\
\text { low educated }\end{array}$ & $\begin{array}{l}\text { Out-migration, } \\
\text { high educated }\end{array}$ & $\begin{array}{l}\text { In-migration, } \\
\text { low educated }\end{array}$ & $\begin{array}{l}\text { In-migration, } \\
\text { high educated }\end{array}$ \\
\hline $\begin{array}{l}\text { EUI I labour migrants, t-I } \\
\mathrm{N}=2,550 \text { (excluding small } \\
\text { municipalities) } \\
\text { Proportions }\end{array}$ & $\begin{array}{l}-0.023 \\
(0.016)\end{array}$ & $\begin{array}{l}-0.054 \\
(0.055)\end{array}$ & $\begin{array}{l}0.006 \\
(0.016)\end{array}$ & $\begin{array}{l}0.060 \\
(0.060)\end{array}$ \\
\hline $\begin{array}{l}\text { EUII labour migrants, } \mathrm{t}-\mathrm{I} \\
\mathrm{N}=27 \mathrm{I} 0 \\
\text { Frequencies }\end{array}$ & $\begin{array}{l}\mathbf{0 . 0 1 2 * *} \\
(0.004)\end{array}$ & $\begin{array}{l}\mathbf{0 . 0 0 9} * * \\
(0.003)\end{array}$ & $\begin{array}{l}\mathbf{0 . 0 1 2} \text { (2* } \\
(0.004)\end{array}$ & $\begin{array}{l}0.005 \\
(0.004)\end{array}$ \\
\hline $\begin{array}{l}\text { EUI I labour migrants, } \mathrm{t}-\mathrm{I} \\
\mathrm{N}=2,550 \text { (excluding large } \\
\text { municipalities) } \\
\text { Frequencies }\end{array}$ & $\begin{array}{l}-0.010 \\
(0.006)\end{array}$ & $\begin{array}{l}-0.004 \\
(0.004)\end{array}$ & $\begin{array}{c}0.008 \\
(0.006)\end{array}$ & $\begin{array}{l}\mathbf{0 . 0 1 0 *} \\
(0.005)\end{array}$ \\
\hline
\end{tabular}

(Standard errors in parenthesis)

$* * *$ Sig< $<=0.00 \mathrm{I}, * *$ Sig $<=0.0 \mathrm{I}, *$ Sig $<=0.05$.

Source: Statistics Norway and Microdata.no

The second row depicts the results from models that are identical to those in Table 11.3, except that all variables are measuring frequencies, instead of proportions. The results are drastically different; for instance, the results display a significant positive relationship between EU11 migrants and outmigration. The reason is that Norway's rural municipalities are of very different sizes, which means that the larger rural municipalities will have an extremely strong effect in a model with frequencies. Because a few of the larger municipalities (with roughly 18,000 inhabitants) experienced an increase in out-migration that was relatively small, but very high in absolute numbers, the results changed.

In the third row, the 16 largest rural municipalities (which have more than 8,000 inhabitants) have been removed from the analysis. The results from these regressions are similar to the results in Table 11.3, thus strengthening the conclusion that the connection between international labour migration and Norwegian-born internal migration is weak and insignificant. When the number of EU11 labour migrants increases with one per cent, out-migration decreases and in-migration increases, but the coefficients are close to zero and not significant, except for the in-migration of more highly educated people.

Models with control for housing prices (based on the price per square meter) were tested as well, but about half of the rural municipalities have missing values for this variable, so it is therefore not included in the presented analyses. The results were not altered after controlling for housing prices, which had no significant effect on internal migration in rural municipalities.

My overall interpretation of the results is that there is no significant systematic connection between international labour migration and Norwegian-born 
internal mobility patterns. There is a tendency for higher international labour migration to attract more highly educated natives, but this correlation is weak and not robust enough to argue that there is any clear connection between these two phenomena.

\section{International labour migration as demographic refill and expansion of the rural labour market: discussion and conclusion}

Norway's rural areas have experienced an unprecedented increase in labourrelated migration in the years since the enlargement of the EU. The present analyses show that, overall, the internal migration of Norwegian-born people in rural areas is unaffected by international labour migration. This has several important implications.

First, the results suggest that, overall, the migrant's role in the rural labour market is mainly an expansion - new jobs are created and filled by migrants. There are no signs of a displacement of less-educated Norwegian-born people. Municipalities that, over time, have received many labour migrants have seen no significant change in the in- and out-migration of their lesseducated workers. The hypotheses claiming there should be visible changes rest on two main assumptions. First, that the less-educated workers would, to some degree, compete with the migrants and that their wages and employment opportunities are negatively affected by the migrants' presence. Second, it was assumed that these effects are relevant and important enough to affect workers' settlement decisions. We can speculate that both assumptions, to some degree, are invalid. Although an analysis of settlement decisions cannot say anything directly about labour market outcomes for natives, the results suggest that the effect of international labour migration on natives' wages and employment cannot be particularly strong in rural areas. If it was, we would likely see some change, if not in out-migration (which could be counteracted by a de-commodifying welfare state or strong place attachment), at least in in-migration of the less educated. If increasing international labour migration has no effect on the in-migration of Norwegian-born people without a higher education, it likely means that their employment opportunities are not negatively affected in any major way. Rather than labour migrants and lesseducated Norwegian-born workers being in competition, it seems more likely that they are often operating in different segments of the labour market (Piore 1979). Further, even if international labour migration has a significant effect on natives' wages and employment opportunities, which some Norwegian studies have indicated (Bratsberg and Raaum 2012, Hoen, Markussen, and Roed 2018, Slettebak in press) these effects might not be sufficient to affect the settlement decisions of Norwegian-born workers. Strong place attachment to the rural area, or a strongly de-commodifying welfare state, could counteract 
the economic incentives and perhaps explain why the (rural) Norwegian case is different from the British, Italian, or American cases.

Despite the above, an alternative explanation, one that involves the economic climate of the times, should also be discussed. It is possible to argue that, although we cannot observe any systematic effects of international labour migration on internal migration, we do not know what would have happened in a counterfactual scenario where rural industries experienced booms (such as the fish-farming industry in Norway, which has also occurred during the period under study), but without the option of recruiting labour migrants. One possibility is perhaps the higher in-migration of natives to the booming industry. In this scenario, international labour migrants have cancelled out the in-migration of natives. In other words, the results suggest that labour migrants' roles in the rural labour market are mainly an expansion, but they might have replaced (some) natives who would otherwise have migrated to the municipalities with booming industries. However, it is unlikely that employers within, for instance, the fish-processing industry, would have managed to recruit enough native workers, at least not without improving wages and working conditions. Without cheap and flexible labour, higher capital investments (such as investments in machines) might have been a more likely development.

Further, it is interesting that this expansion, both in the labour market and in the population in general, has not resulted in a higher demand for more highly educated native workers. In many cases, international migration has led to a significantly higher number of inhabitants, which in theory would require increasing numbers of doctors, nurses, teachers, and other professions that require strong Norwegian language skills and higher education. Although there is a tendency toward a lower net-loss of highly educated workers in municipalities with larger labour migrant populations, this correlation is weak and not systematic. A possible explanation could be that, in many peripheral municipalities, labour migrants (or other migrants) themselves help to fill these high-competence jobs. Although the majority of EU11 labour migrants work in manual and low-skilled jobs (Friberg 2016), not all of them do. In a study of the regions of western Norway, Båtevik and Grimsrud (2017) found that the peripheral regions receive relatively more high-competence workers, such as those in the academic professions, through international labour migration than the central regions do, thus reducing the traditional 'peripheral disadvantages.' They also, however, note that there are big differences among the peripheral regions. Some receive many highly skilled migrants, while others receive very few, which might help explain the weak and unsystematic results emerging from this analysis.

Second, the results clearly show that international labour migration benefits rural municipalities that are otherwise struggling with depopulation. While many studies reviewed in this chapter found that international migration is 
associated with increasing rates of out-migration among natives, no such effects are found in the case of rural Norway. Labour migrants from EU11 are mainly adding to the population, giving a much-needed 'demographic refill' to many rural areas (Hedberg and Haandrikman 2014).

Third, the results of these analyses show that it is unlikely that the results from spatial correlation exercises on the effect of international migration on native wages and employment are biased, due to the selective out-migration of natives in rural Norway. Further research is required to determine whether these results are more generally representative for rural areas in western Europe.

\section{Acknowledgements}

The chapter is result of the 2017-2022 Global Labour in Rural Societies research project financed by the Norwegian Research Council (grant no. 261854/ F10). The author wishes to thank the external reviewers for their comments on the manuscript. Funding from the Norwegian University of Science and Technology has made possible open access publishing of the chapter.

\section{References}

Almås, R and K.M. Elden. 1997. Den rurale dimensjonen. En teoretisk og geografisk avgrensning, Trondheim: Centre for Rural Research.

Aure, M., A. Førde and T. Magnussen. 2018. 'Will Migrant Workers Rescue Rural Regions? Challenges of Creating Stability through Mobility.' Journal of Rural Studies 60: 52-59. doi.org/10.1016/j.jrurstud.2018.03.005.

Bayona-i-Carrasco, J. and F. Gil-Alonso. 2013. 'Is Foreign Immigration the Solution to Rural Depopulation? The Case of Catalonia (1996-2009).' Sociologia Ruralis 53(1): 26-51. doi.org/10.1111/j.1467-9523.2012.00577.x.

Blau, F. and L. Kahn. 2012. 'Immigration and the Distribution of Incomes.' NBER Working Paper Series: 18515. doi.org/10.3386/w18515.

Borjas, G. 2003. 'The Labor Demand Curve is Downward Sloping: Reexamining the Impact of Immigration on the Labor Market.' Quarterly Journal of Economics cxviii(4): 1335-1374.

Borjas, G. 2006. 'Native Internal Migration and the Labor Market Impact of Immigration.' The Journal of Human Resources 41(2): 221-258.

Borjas, G., R.B. Freeman and L.F. Katz. 1997. 'How Much do Immigration and Trade Affect Labor Market Outcomes?' Brookings Papers on Economic Activity 1997(1): 1-90. doi.org/10.2307/2534701.

Brama, A. 2006. " White flight"? The production and reproduction of immigrant concentration areas in Swedish cities, 1990-2000.' Urban Studies 43(7): 1127. doi.org/ 10.1080/00420980500406736.

Bratsberg, B. and O. Raaum. 2012. 'Immigration and Wages: Evidence from Construction.' Economic Journal 122(565): 1177-1205. doi.org/10.1111/ j.1468-0297.2012.02540.x. 
Bratsberg, B., O. Raaum, M. Røed and P. Schøne. 2014. 'Immigration Wage Effects by Origin.' Scandinavian Journal of Economics 116(2): 356-393. doi.org/10.1111/ sjoe. 12053 .

Brücker, H., S. Fachin and A. Venturini. 2011. 'Do Foreigners Replace Native Immigrants? A Panel Cointegration Analysis of Internal Migration in Italy.' Economic Modelling 28(3): 1078-1089. doi.org/10.1016/j.econmod.2010.11.020.

Båtevik, F.O. and G.M. Grimsrud. 2017. 'Kapittel 3: Nye sentrum-periferi-mønster.' In Immateriell kapital, edited by J.R. Andersen, E. Bjørhusdal, J.G. Nesse, T. Årethun, 49-68. Oslo: Universitetsforlaget.

Card, D. 1990. 'The Impact of the Mariel Boatlift on the Miami Labor Market.' Industrial and Labor Relations Review 43(2): 245-257. doi.org/10.1177/ 001979399004300205.

Card, D. 2001. 'Immigrant Inflows, Native Outflows, and the Local Labor Market Impacts of Higher Immigration.' Journal of Labor Economics 19(1): 22-64. doi.org/ $10.1086 / 209979$.

Card, D. 2009. 'Immigration and Inequality.' American Economic Review 99(2): 1-21. doi.org/10.1257/aer.99.2.1.

Card, D. and J. DiNardo. 2000. 'Do Immigrant Inflows Lead to Native Outflows?' American Economic Review 90(2): 360-367. doi.org/10.1257/aer.90.2.360.

Crowder, K., M. Hall and S.E. Tolnay. 2011. 'Neighborhood Immigration and Native Out-Migration.' American Sociological Review 76(1): 25-47. doi.org/10.1177/ 0003122410396197.

Doeringer, P.B. and M. Piore. 1971. Internal Labor Markets and Manpower Analysis. New York: D.C Heath and Company.

Dzamarija M.T. 2013. Innvandringsgrunn 1990-2011, hva vet vi og hvordan kan statistikken utnyttes? Oslo: Statistisk sentralbyrå.

Esping-Andersen, G. 1990. The Three Worlds of Welfare Capitalism. Cambridge: Polity Press.

Farstad, M., J.F. Rye and R. Almås. 2009. By, bygd og fritidsboliger 2008. Kommentert frekvensrapport, Trondheim: Centre for Rural Research.

Frey, W. 1996. 'Immigration, Domestic Migration, and Demographic Balkanization in America: New Evidence for the 1990s.' Population and Development Review 22(4): 741-763. doi.org/10.2307/2137808.

Friberg, J.H. 2016. Arbeidsmigrasjon. Hva vet vi om konsekvensene for norsk arbeidsliv, samfunn og økonomi? Oslo: Fafo.

Gonzalez, L. and F. Ortega. 2013. 'Immigration and Housing Booms: Evidence from Apain*.' Journal of Regional Science 53(1): 37-59. doi.org/10.1111/jors.12010.

Grimsrud, G.M. 2011. 'How Well Does the "Counter-urbanisation Story" Travel to Other Countries? The Case of Norway.' Population, Space and Place 17(5): 642-655. doi.org/10.1002/psp.655.

Hatton, T.J. and M. Tani. 2005. 'Immigration and Inter-Regional Mobility in the UK, 1982-2000.' Economic Journal 115 (507): F342-F358. doi.org/10.1111/ j.1468-0297.2005.01039.x.

Hedberg, C. and K. Haandrikman. 2014. 'Repopulation of the Swedish Countryside: Globalisation by International Migration.' Journal of Rural Studies 34: 128-138. 
Hoen, M., S. Markussen and K. Røed. 2018. 'Immigration and Social Mobility.' IDEAS Working Paper Series from RePEc.

Høydahl, E. 2017. 'Ny sentralitetsindeks for kommunene.' Statistics Norway. Document 40.

King, R. and R. Skeldon. 2010. “"Mind the Gap!” Integrating Approaches to Internal and International Migration.' Journal of Ethnic and Migration Studies 36(10): 16191646. doi.org/10.1080/1369183X.2010.489380.

Mocetti, S. and C. Porello. 2010. 'How Does Immigration Affect Native Internal Mobility? New Evidence from Italy.' Regional Science and Urban Economics 40(6): 427-439. doi.org/10.1016/j.regsciurbeco.2010.05.004.

Piore, M.J. 1979. Birds of Passage. Migrant Labor and Industrial Societies. New York: Cambridge University Press.

Rye, J.F. and M.H. Slettebak. 2020. 'The New Geography of Labour Migration: EU11 Migrants in Rural Norway.' Journal of Rural Studies 75: 125-131.

Saiz, A. 2007. 'Immigration and Housing Rents in American cities.' Journal of Urban Economics 61(2): 345-371. doi.org/10.1016/j.jue.2006.07.004.

Sørlie, K. 2009. Bolyst og stedsattraktivitet: motiver for å flytte og bo i distriktene. Oslo: Norsk institutt for by- og regionforskning.

Sørlie, K. 2010. 'Bosetting, flytting og regional utvikling.' In Det norske samfunn, edited by I. Frønes and L. Kjølsrød, 457-478. Oslo: Gyldendal akademisk.

Statistics Norway (n.d.) 'Innvandrere og norskfødte med innvandrerforeldre'. https:// www.ssb.no/statbank/table/07110/.

Wessel, T. and V. Nordvik. 2019. 'Mixed Neighbourhoods and Native Out-mobility in the Oslo Region: The Importance of Parenthood.' Urban Studies 56(5): 885-905. doi.org/10.1177/0042098018768452.

Wright, R.A., M. Ellis and M. Reibel. 1997. 'The Linkage between Immigration and Internal Migration in Large Metropolitan Areas in the United States.' Economic Geography 73(2): 234-254. doi.org/10.1111/j.1944-8287.1997.tb00069.x. 